\title{
Multiple pilomatricomas: Recurrent skin nodules in myotonic dystrophy
}

\author{
Renee K Eng ${ }^{1}$, Ahmed Shehabeldin ${ }^{1}$, Megan Ketcham ${ }^{1}$, Parul Shah ${ }^{2}$, Seema Mullick ${ }^{3}$, Jae Y Ro*1 \\ ${ }^{1}$ Department of Pathology and Genomic Medicine, Houston Methodist Hospital, Houston, TX, USA \\ ${ }^{2}$ Department of Internal Medicine, Houston Methodist Sugar Land Hospital, Sugar Land, TX, USA \\ ${ }^{3}$ Department of Pathology and Genomic Medicine, Houston Methodist Sugar Land Hospital, Sugar Land, TX, USA
}

Received: July 2, 2020

DOI: $10.5430 /$ crcp.v7n1p34
Accepted: October 11, 2020

Online Published: October 25, 2020

\begin{abstract}
Pilomatricoma is a relatively uncommon benign tumor derived from the matrix of hair follicles. Multiple pilomatricomas may arise sporadically or in association with other disease entities. These entities include myotonic dystrophy type-1, a multisystem disorder that confers increased susceptibility to developing neoplasms, as well as familial adenomatous polyposis-related syndromes (including Gardner syndrome) and others. Here we present two case reports of multiple pilomatricomas that were initially misidentified clinically. We discuss pilomatricoma as a differential diagnosis of multiple skin nodules, its association with myotonic dystrophy in one of two patients, and describe its distinguishing microscopic features. We emphasize the importance of screening patients with multiple pilomatricomas for various syndromes that predispose to malignancy.
\end{abstract}

Key Words: Pilomatricoma, Pilomatrixoma, Multiple, Myotonic dystrophy, Recurrent, Head and neck

\section{INTRODUCTION}

Pilomatricoma (also known as pilomatrixoma) is a benign tumor derived from the matrix of hair follicles. The majority of cases appear in patients younger than 20 years old, though a second peak in incidence has been reported in the sixth decade. ${ }^{[1]}$ Clinically, the lesions are described as hard, well-circumscribed, slow-growing masses covered by normal-appearing or bluish-colored skin. ${ }^{[1]}$ The lesions occur most commonly on the face and neck but may occur elsewhere. Lesions are usually solitary but multiple pilomatricoma is seen in approximately $2.5 \%$ of cases. ${ }^{[2,3]}$ Multiple pilomatricomas may occur sporadically without any other associated disease but there have been several reports of cases with multiple pilomatricomas arising in association with various syndromes, most involving myotonic dystrophy and familial adenomatous polyposis-related syndromes (including Gardner syndrome). ${ }^{[4]}$ Other syndromes include Turner syndrome, Rubinstein-Taybi syndrome, Sotos syndrome (relatively scant), and Kabuki syndrome. ${ }^{[4]}$ Pilomatricomas have also been linked to infection with polyomavirus, a non-enveloped, double-stranded DNA virus that induces many types of tumors. In mice, polyomavirus infection induces pilomatricomas expressing viral VP-1 proteins in mature ghost cells. ${ }^{[5]}$ These viral VP-1 proteins may contribute to tumorigenesis in human pilomatricomas. ${ }^{[6]}$

Histologically, the tumors are composed of three components: basaloid cells, ghost cells, and intervening stroma. The basaloid cells are peripherally located, monotonous, small cells with scant cytoplasm. The more centrally located ghost cells contain abundant eosinophilic cytoplasm with distinct borders and a characteristically absent nucleus. The transition

*Correspondence: Jae Y Ro; Email: jaero@houstonmethodist.org; Address: 6565 Fannin Street, Houston, TX 77030, USA. 
between the basaloid cells and ghost cells can be abrupt. In some cases, a population of cells with pyknotic nuclei and more eosinophilic cytoplasm can be seen. The intervening stroma often contains calcifications and, in the case of rupture, foreign body-type giant cells. Immunohistochemical staining with $\beta$-catenin reveals prominent nuclear and cytoplasmic staining of basophilic cells and negative staining of ghost cells. In comparison, normal epidermal cells show weak and patchy membranous $\beta$-catenin staining. The migration of $\beta$-catenin from membranes to the cytoplasm and nucleus supports the hypothesis that $\beta$-catenin mutations contribute to the tumorigenesis of pilomatricoma. ${ }^{[7]}$ Activating mutations of CTNNB1 encoding $\beta$-catenin may be a mechanism of cell proliferation in pilomatricomas. ${ }^{[7]} \beta$-catenin is involved in the Wnt/Wingless signaling pathway (responsible for various aspects of cell development), epithelial adhesion and communication, and regulation of cell growth and behavior. Studies using transgenic mice have shown that mutated, stabilized forms of $\beta$-catenin can lead to increased de novo hair follicle formation and pilomatricomas. ${ }^{[8]}$ In $75 \%$ of pilomatricomas, single nucleotide substitutions stabilize $\beta$ catenin and prevent ubiquitin degradation. ${ }^{[7,9]}$ In cases of ambiguous histology, $\beta$-catenin could be a helpful marker for diagnosis in both sporadic and syndromic pilomatricomas.

Here we present two cases of multiple pilomatricomas. Though one patient had a history of myotonic dystrophy, the other had no previous history of any genetic syndromes. We review recent literature on multiple pilomatricomas and discuss their clinical and pathological features.

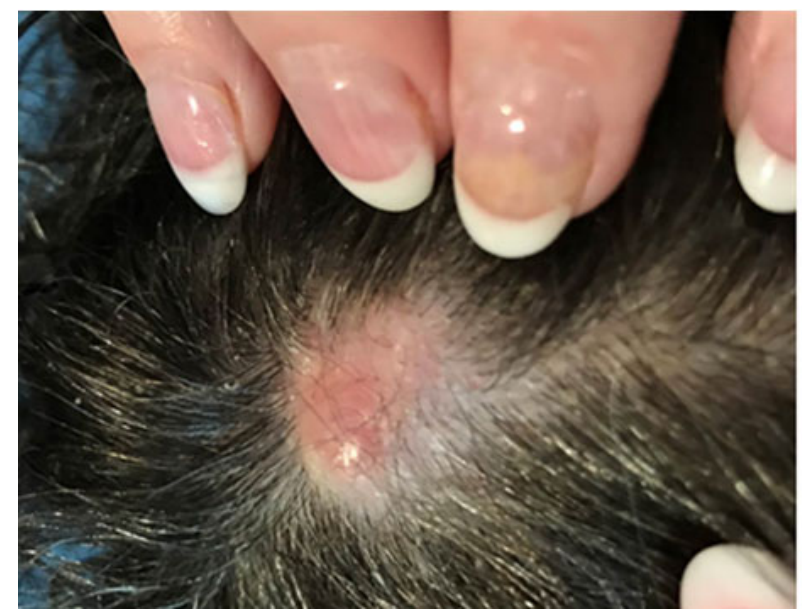

\section{Case PResentation}

\subsection{Case 1}

A 64-year-old woman with a history of myotonic dystrophy type-1 and multiple medical comorbidities who presented with multiple scalp and neck pilomatricomas reported having multiple, similar scalp nodules since age 18 . She had many removed in her lifetime with up to 15 nodules removed at once. Multiple family members also had recurrent scalp nodules, including her father.

In 2014, the patient reported four scalp nodules: one right frontal $(3 \mathrm{~cm} \times 2 \mathrm{~cm}$ ), two middle occipital (both $1 \mathrm{~cm} \times$ $1 \mathrm{~cm})$, and one posterior scalp $(2 \mathrm{~cm} \times 2 \mathrm{~cm})$. At the time, the patient stated that the frontal and posterior nodules were tender and the frontal nodule was enlarging. All four nodules were clinically diagnosed as sebaceous cysts. After complete excision, pathological diagnosis revealed pilomatricomas.

In 2017, the patient reported ten new nodules: one right temporal $(0.5 \mathrm{~cm} \times 0.5 \mathrm{~cm})$, one right forehead $(1.5 \mathrm{~cm} \times 1 \mathrm{~cm})$, one left occipital $(2.5 \mathrm{~cm} \times 2 \mathrm{~cm})$, one posterior midline head $(1.5 \mathrm{~cm} \times 1.5 \mathrm{~cm})$, three right posterior neck $(0.5 \mathrm{~cm} \times$ $0.5 \mathrm{~cm}, 0.5 \mathrm{~cm} \times 0.5 \mathrm{~cm}$, and $1 \mathrm{~cm} \times 1 \mathrm{~cm})$, and two left posterior neck $(1.5 \mathrm{~cm} \times 1 \mathrm{~cm}$ and $0.5 \mathrm{~cm} \times 0.5 \mathrm{~cm})$ (see Figure 1). All of the nodules had developed in the time since the last resection. The right forehead and posterior midline head nodules were described as tender. The nodules were again clinically diagnosed as sebaceous cysts. Complete excision of all nodules was performed and a pathologic diagnosis of pilomatricoma was made from all nodules.

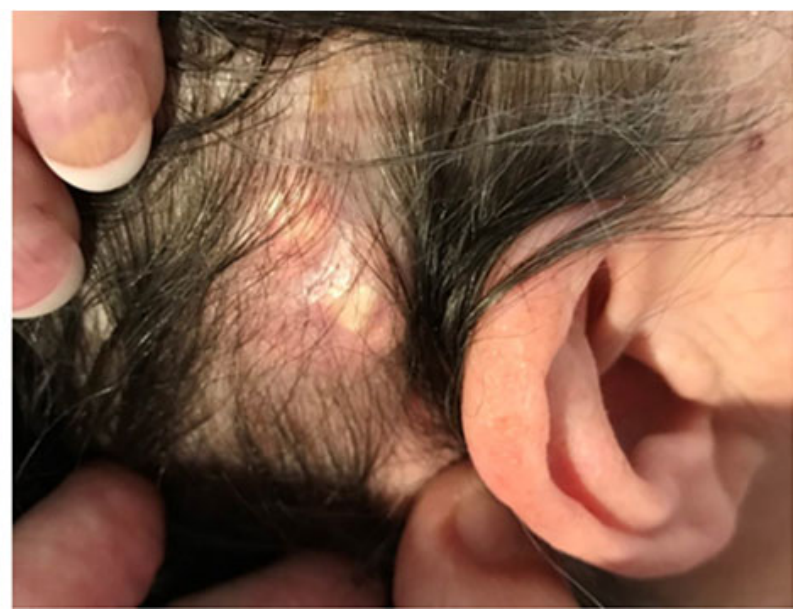

Figure 1. Multiple tender head nodules in a patient with myotonic dystrophy, clinically diagnosed as sebaceous cysts

In her lifetime, this patient had at least 14 pilomatricomas that were documented at this hospital (and possibly up to 29 pilomatricomas per a self-reported history). All of the nodules were limited to the head and neck region.
The patient was diagnosed with myotonic dystrophy in her thirties and reported a strong family history of myotonic dystrophy with her father, brother, sister, and multiple other relatives also developing the disorder. Other pertinent medical 
conditions included a diagnosis of invasive ductal carcinoma of the breast in 2017.

In addition to myotonic dystrophy, the family history included multiple types of cancer including prostate, lung, breast, and pancreas.

\subsection{Case 2}

A 49-year-old woman with multiple medical comorbidities who presented with right and left forearm pilomatricomas reported having 13 similar nodules previously. These nodules had involved her right ear, left neck, scalp, torso, and both legs and arms.

In 2017, the patient developed two new lesions on the right and left posterior forearm. Clinically, the nodules were di- agnosed as epidermal inclusion cysts. Complete excision of all nodules was performed and a pathologic diagnosis of pilomatricoma was made from all nodules.

Additionally, the patient had a borderline phyllodes tumor of the breast, colonic tubular adenomas, and cervical low-grade dysplasia. Her family history included lung cancer in both her mother and maternal grandmother.

\subsection{Histologic findings and immunohistochemical find- ings}

Two distinct populations of cells with peripherally-located basaloid cells (see Figure 2A) and centrally-located ghost or shadow cells with focal calcification (see Figure 2B). Stromal calcification and multinucleated giant cell reaction denoting rupture are seen (see Figure 2C).

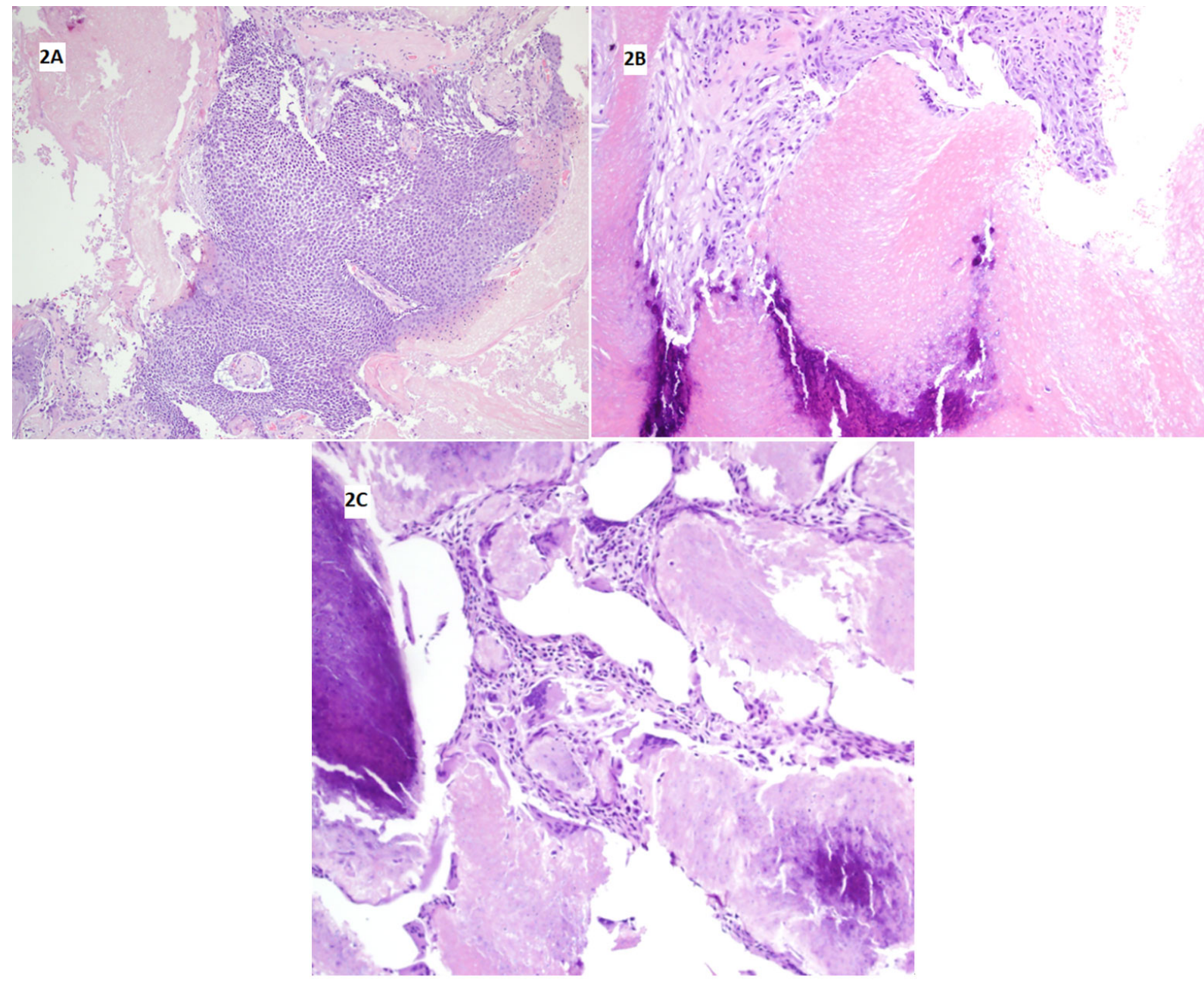

Figure 2. Histologic Findings. Two distinct populations of cells with peripherally-located basaloid cells (2A) and centrally-located ghost or shadow cells with focal calcification (2B), Stromal calcification and multinucleated giant cell reaction denoting rupture $(2 \mathrm{C})$. 
$\beta$-catenin immunostain with nuclear and cytoplasmic staining of basaloid cells and no stain in ghost cells (see Figure 3B) with corresponding H\&E (see Figure 3A).

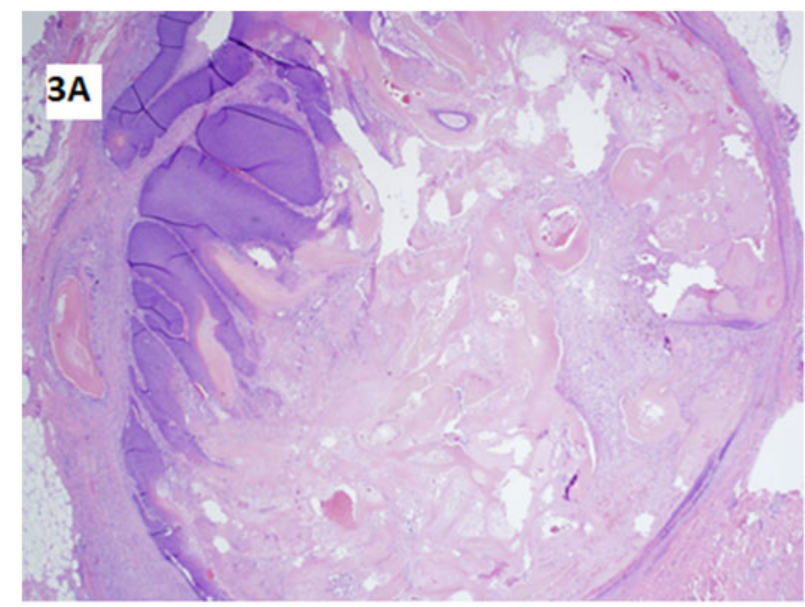

Approval and requirement of formal written consent were waived by the Institutional Review Board of Houston Methodist Hospital.

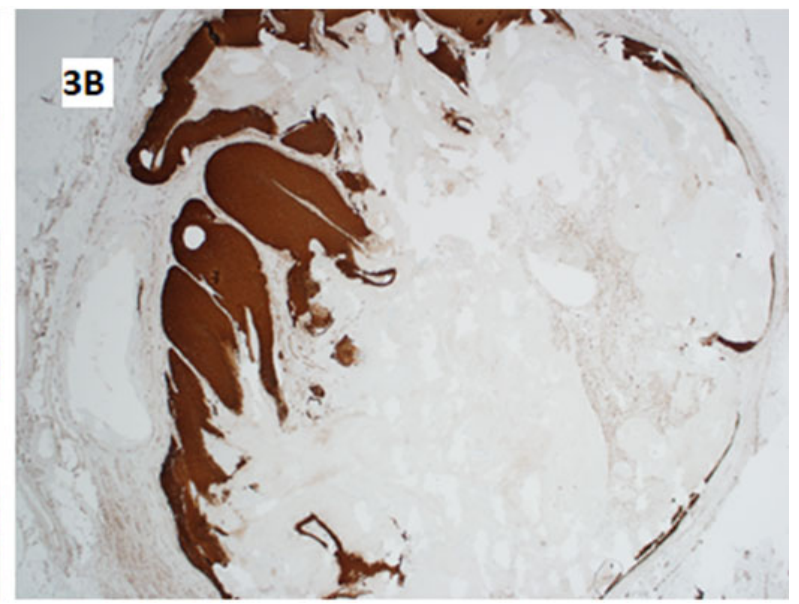

Figure 3. Immunohistochemical Findings. $\beta$-catenin immunostain with nuclear and cytoplasmic staining of basaloid cells and no stain in ghost cells (3B) with corresponding H\&E (3A).

\section{Discussion}

Pilomatricomas are a type of skin tumor that associate with hair follicles. The pilomatricomas in Case 1 were restricted to the head and neck region. The patient in Case 2, however, reported pilomatricomas throughout her body including the head and neck region, and upper and lower extremities. In a large review, $50.6 \%$ of pilomatricomas were reported to occur on the head, $17.6 \%$ on the neck, $15.3 \%$ on the upper extremities, $7.2 \%$ on the back, and $2 \%$ on the lower extremities. ${ }^{[3]}$ Both cases presented here are consistent with the findings in the literature.

Clinically, pilomatricomas usually present as non-tender, firm masses. However in the literature, $35 \%$ of cases present with pain and tenderness. ${ }^{[3]}$ Our first patient described tenderness in 4 of the 14 pilomatricomas seen during her medical encounters. As those masses were located in the extreme anterior and posterior regions of the head, they are possibly more susceptible to compression from daily activities.

Histologically, pilomatricomas are composed of the classic triad of basaloid cells, ghost or shadow cells, and intervening stroma with calcifications. These cells were seen in both of the cases described herein (see Figure 2). Hashimoto, et al. described pilomatricomas on electron microscopy and demonstrated that the basaloid cells and ghost cells are hair cortical cells on a continuum of maturation. This may explain why newer lesions are predominantly composed of basaloid cells while established lesions have more ghost cells. Basaloid cells resemble embryonic cortical cells as well as anagen adult hair in the lower levels of the keratoge- nous zone. Ghost cells, which contain keratin strains and lack a plasma membrane or nucleus, represent embryonic cortical cells at an advanced stage of keratinization. Additionally, hair-like structures, cells resembling the cuticular cells of the cortex, and cells of the inner root sheath have been described. ${ }^{[10]}$

Clinically and radiologically, pilomatricomas have been misidentified as sebaceous cysts, epidermoid cysts, dermoid cysts, lipomas, or foreign body reactions. ${ }^{[1,3]}$ The patient in Case 1 was clinically diagnosed as having sebaceous cysts multiple times, while the patient in Case 2 was diagnosed with epidermoid cysts. Pathologically, pilomatricomas may be misdiagnosed as epidermoid or dermoid cysts, calcified lymph nodes, calcified hematomas, hemangiomas, or parotid gland tumors if located in the cheek region. ${ }^{[1]}$

Malignant transformation into pilomatrix carcinoma is rare. The location and symptoms of pilomatrix carcinoma are similar to benign pilomatricoma. However, pilomatrix carcinoma occurs in the 5th to 7th decade with a male predominance. Histologic features indicating malignant transformation include cytologic atypia, pleomorphism, infiltration into surrounding structures, abundant mitoses, and necrosis. These features were absent in the pilomatricomas of both patients. At a recurrence rate of $31 \%$ within an average of 6.5 months, pilomatrix carcinoma has greatly increased recurrence compared to pilomatricoma. ${ }^{[12]}$ Metastasis, primarily to the lungs or lymph nodes, has also been described in approximately $10 \%$ of cases. ${ }^{[13]}$ The standard treatment for pilomatricoma is complete surgical excision. After successful excision, pi- 
lomatricomas have a very low recurrence rate of 1.5\%-6\%, occurring within an average of 1.6 years. ${ }^{[3]}$ In our two cases, complete surgical excision was performed and no recurrence was reported.

Pilomatricomas may be the first sign of an underlying syndrome. In $46 \%$ of cases, multiple pilomatricomas arising in the setting of familial syndromes show six or more pilomatricomas. Conversely, sporadic cases of multiple pilomatricomas have five or fewer lesions in $95 \%$ of cases. Therefore, clinicians should screen for underlying syndromes if a patient has developed more than six pilomatricomas or fewer than six in the context of a family history of the above syndromes. Myotonic dystrophy has the strongest link to multiple pilomatricomas with $41 \%$ of patients developing more than six pilomatricomas. Additionally, $41 \%$ of patients develop pilomatricomas before being diagnosed with myotonic dystrophy. ${ }^{[4]}$

Myotonic dystrophy is part of a group of autosomal dominant disorders with high penetrance that show skeletal and respiratory muscle weakness and myotonia. Other symptoms may include cardiac muscle abnormalities and conduction defects, cataracts, daytime somnolence, endocrine disorders, and an increased susceptibility to developing neoplasms- the most common being pilomatricomas. Myotonic dystrophy is caused by unstable nucleotide repeat expansions in untranslated regions of genes. The more common myotonic dystrophy type- 1 is caused by an unstable trinucleotide (CTG) expansion of the 3' region of the dystrophia myotonica-protein kinase (DMPK) gene. The less common myotonic dystrophy type-2 is caused by an unstable tetranucleotide (CCTG) repeat in the zinc finger protein 9 (ZNF9) gene. The two genes involved in the various types of myotonic dystrophy are unrelated but show similar symptoms. It is theorized that the genetic instability that causes this disorder may also lead to neoplasms in these patients. ${ }^{[14]}$ In Drosophila flies, mutations in the tumor suppressor LATS1/warts gene, which has homol- ogy to the human DMPK gene, leads to excess growth and abnormalities in cell differentiation. Thus, DMPK may function as a tumor suppressor gene within the $\mathrm{Wnt} / \beta$-catenin pathway that is also implicated in pilomatricoma tumorigenesis. ${ }^{[15]}$

The patient in Case 1 was diagnosed with myotonic dystrophy in her thirties and may have had up to 29 pilomatricomas throughout her lifetime per her history. Her first scalp nodule formed at the age of 18 . Though records could not be located, the first nodule was likely a pilomatricoma as it shared clinical similarities to her current pilomatricomas. Because of her family history, a screening was warranted and may have facilitated an earlier myotonic dystrophy diagnosis. Additionally, the patient later developed breast invasive ductal carcinoma.

The patient in Case 2 reported having up to 15 pilomatricomas throughout her lifetime, in addition to a breast borderline phyllodes tumor, colonic tubular adenoma, and cervical squamous low-grade dysplasia. However, unlike the patient in Case 1, she did not have a family history of syndromes. Only $5 \%$ of patients with sporadic pilomatricomas develop more than 6 , and this patient greatly exceeded that number. ${ }^{[4]}$ Though genetic testing has not been performed, this patient would benefit from extensive testing for an underlying, undiagnosed syndrome.

In conclusion, pilomatricoma is an uncommon tumor that should be kept on the differential as not to be misdiagnosed. Multiple pilomatricomas (greater than 6) should raise suspicion for an underlying genetic syndrome, including myotonic dystrophy. Additionally, patients with a family history of syndromes who develop pilomatricomas should be screened. Though these tumors are benign, they may indicate an underlying disorder in patients who present with multiple masses.

\section{Conflicts of InTERest Disclosure}

We declare that we have no conflict interests.

\section{REFERENCES}

[1] Çevik HB, Erkan M, Kayahan S, et al. A skin tumor from an orthopedic oncology perspective: Pilomatrixoma in extremities (11 years experience with 108 cases). Dermatol Ther. 2019 Sep; 32(5): e13004. PMid:31241214. https://doi.org/10.1111/dth.13004

[2] Guinot-Moya R, Valmaseda-Castellon E, Berini-Aytes L, et al. Pilomatrixoma. Review of 205 cases. Med Oral Patol Oral Cir Bucal 2011 Jul 1; 16(4): e552-5. PMid:20711110. https ://doi .org/10 $.4317 /$ medoral. 16. e552

[3] Pirouzmanesh A, Reinisch JF, Gonzalez-Gomez I, et al. Pilomatrixoma: a review of 346 cases. Plast Reconstr Surg. 2003 Dec;
112(7): 1784-9. PMid:14663221. https://doi.org/10.1097/01 .PRS. 0000091160.54278 .64

[4] Ciriacks K, Knabel D, Waite MB. Syndromes associated with multiple pilomatricomas: When should clinicians be concerned? Pediatr Dermatol. 2020 Jan; 37(1): 9-17. PMid:31618803. https: //doi.org/10.1111/pde.13947

[5] Símula S, Ozuna PV, Otero J, et al. Polyomavirus-induced pilomatricomas in mice: from viral inoculation to tumour development. APMIS. 2012 May; 120(5): 397-404. PMid:22515294. https://doi.org/10.1111/j.1600-0463.2011.02839.x

[6] Sanjuán NA, Símula $S$, Casas J, et al. Detection of polyomavirus major capsid antigen (VP-1) in human pilomatricomas. Medicina (B 
Aires). 2010; 70(2): 159-62. PMid: 20447899.

[7] Kajino Y, Yamaguchi A, Hashimoto N, et al. $\beta$-Catenin gene mutation in human hair follicle-related tumors. Pathol Int. 2001 Jul; 51(7): 543-8. PMid:11472567. https ://doi.org/10.1046/j.1440-1 $827.2001 .01231 . \mathrm{x}$

[8] Gat U, DasGupta R, Degenstein L, et al. De Novo hair follicle morphogenesis and hair tumors in mice expressing a truncated betacatenin in skin. Cell. 1998 Nov 25; 95(5): 605-14.PMid: 9845363. https ://doi.org/10.1016/S0092-8674(00)81631-1

[9] Chan EF. Pilomatricomas contain activating mutations in beta-catenin. J Am Acad Dermatol. 2000 Oct; 43(4): 701-2. PMid: 11004631. https://doi.org/10.1016/S0190-9622(00)70339-2

[10] Hashimoto K, Nelson RG, Lever WF. Calcifying epithelioma of Malherbe. Histochemical and electron microscopic studies. J Invest Dermatol. 1966 Apr; 46(4): 391-408. PMid:5936043. https : //doi.org/10.1038/jid.1966.59

[11] Hawkins DB, Chen WT. Pilomatrixoma of the head and neck in children. Int J Pediatr Otorhinolaryngol. 1985 Mar; 8(3): 215-23. PMid:
3997377. https://doi.org/10.1016/S0165-5876(85) 80082 $-3$

[12] Jones C, Twoon M, Ho W, et al. Pilomatrix carcinoma: 12-year experience and review of the literature. J Cutan Pathol. 2018 Jan; 45(1): 33-38. Epub 2017 Oct 18. PMid: 28914451. https ://doi .org/10 $.1111 /$ cup. 13046

[13] Tselis N, Heyd R, Vogt HG, et al. Pilomatrix carcinoma with lymph node and pulmonary metastases. Strahlenther Onkol. 2006 Dec; 182(12): 727-32. PMid: 17149580. https://doi.org/10.100 7/s00066-006-1600-2

[14] Mueller CM, Hilbert JE, Martens W, et al. Hypothesis: neoplasms in myotonic dystrophy. Cancer Causes Control. 2009 Dec; 20(10): 2009-20. PMid: 19642006. https://doi.org/10.1007/s10552 -009-9395-y

[15] Justice RW, Zilian O, Woods DF, et al. The Drosophila tumor suppressor gene warts encodes a homolog of human myotonic dystrophy kinase and is required for the control of cell shape and proliferation. Genes Dev. 1995 Mar 1; 9(5): 534-46. PMid:7698644. https://doi.org/10.1101/gad.9.5.534 